International Journal of Pharmaceutics \& Pharmacology

\title{
Effect of Pravastatin on Development of Diabetes Mellitus - A Statement of Review
}

\author{
Ramu $G^{* 1}$, Bhavya $\mathrm{CH}^{2}$, Vamshi $\mathrm{KD}^{1}$ and Manisha $S^{1}$ \\ ${ }^{1}$ Bharat School of Pharmacy, Mangalpally, Ibrahimpatnam, Ranga Reddy, Telangana, P.O 501510, India \\ ${ }^{2}$ Bharat Institute of Technology, Mangalpally, Ibrahimpatnam, Ranga Reddy, Telangana, P.O 501510, India
}

Article info

Received 01 December 2020

Revised 13 December 2020

Available Online 31 Dec 2020

*Corresponding author: Ramu G, Bharat School of Pharmacy, Mangalpally, Ibrahimpatnam, Ranga reddy, Telangana, P.O 501510, India.

\begin{abstract}
According to the ADA, diabetes mellitus is defined as having fasting blood glucose levels $>=7.0 \mathrm{mmol} / \mathrm{l}$. Statins are the lipid-lowering agents used to treat dyslipidemia and act by inhibiting the HMG Co-A reductase enzyme. Very few studies have reported the results of drugs concerning the profile of blood lipids or which have anti-inflammatory activity behaviour on diabetes. Pravastatin is such a drug that shows inherent beneficial pleiotropic effects on plasma lipids and inflammatory actions. Pravastatin remarkably reduced the increased levels of plasma glucose when compared with the control group, subjecting to no change in body weight or food intake in mice. By performing certain insulin tolerance tests using tracers like 2- [3 H]-deoxy glucose (2DG), they concluded that insulin-induced glucose uptake is increased in adipose tissue. Pravastatin is shown to reduce the circulating concentration of the interleukin-6, cytokines, and TNF-alpha. Pravastatin's anti-inflammatory properties interrupt the natural progression from central obesity to insulin resistance mediated by cytokines from the adipose tissue. Pravastatin can significantly impact selective tissue perfusion through restoring the endothelial function and thus benefit the transportation of glucose and insulin.
\end{abstract}

Keywords: Pravastatin; Diabetes Mellitus; Adiponectin; 2-[3H]deoxyglucose $(2 D G)$

\section{Introduction}

According to the ADA, diabetes mellitus is defined as having fasting blood glucose levels $>=7.0 \mathrm{mmol} / \mathrm{l}$. Statins are the lipid-lowering agents used to treat dyslipidemia and act by inhibiting the HMG Co-A reductase enzyme [1]. Factors that impact diabetes mellitus induction was the focus of extensive research. Pathology predictors such as blood lipids and lipoproteins levels and markers that detect low-level inflammation made their role exist in detecting the occurrence of diabetes mellitus [2-5]. Very few studies have reported the results of drugs concerning the profile of blood lipids or which have anti-inflammatory activity behavior on diabetes. Pravastatin is such a drug that shows inherent beneficial pleiotropic effects on plasma lipids and inflammatory actions. First reported in 2001 in the West Scotland coronary prevention study (WOSCOPS), the relationship between statins and diabetes development. This randomized $40 \mathrm{mg}$ pravastatin placebo-controlled trial showed a $30 \%$ reduction in new diabetes incidence [6].

Pravastatin has a spectrum of anti-athero-thrombotic effects, including the recovery of endothelial and antiinflammatory aspects [7].

\section{Pravastatin and its Mechanism of Action}

Pravastatin and other statins are the competitive inhibitors of the HMG Co-A reductase enzyme, they 
inhibit the de novo synthesis of cholesterol thus depleting the intracellular levels of cholesterol. The lowering of cholesterol causes an increase in LDL receptors on the cell surface that can bind and attribute the circulating LDLs. This results in a decrease in plasma cholesterol.

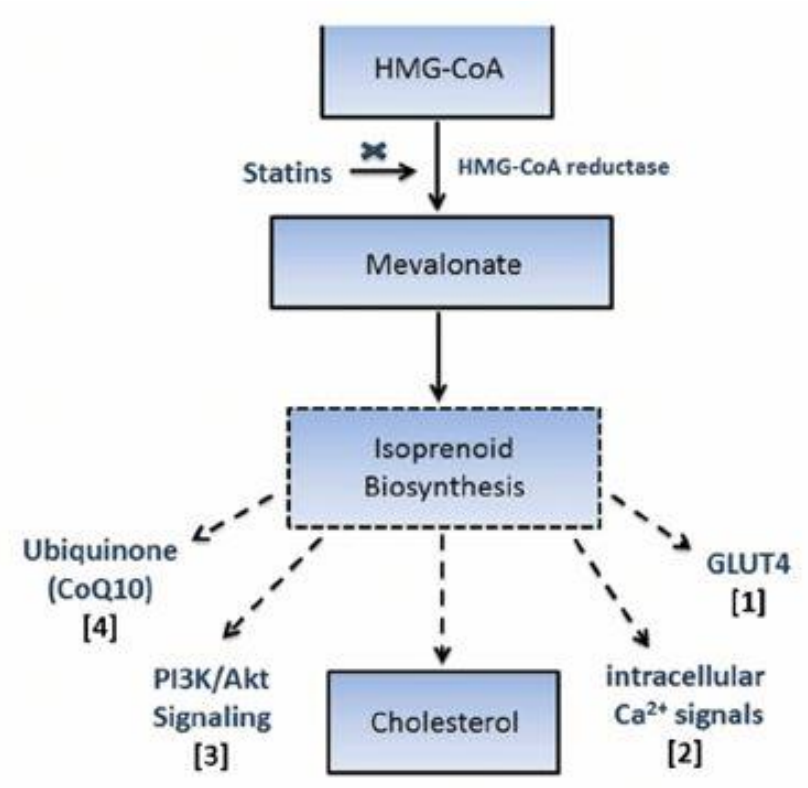

Figure 1: Mechanism of action for statins.

\section{Pravastatin and its Association with the Development of Diabetes}

Several explanations account to explain the association between pravastatin and the occurrence of diabetes mellitus. In a study performed by Takagi et Al. on mice in 2006, pravastatin remarkably reduced the increased levels of plasma glucose when compared with the control group, subjecting to no change in body weight or food intake [8]. By performing certain insulin tolerance tests using tracers like 2- $\left[{ }^{3} \mathrm{H}\right]$-deoxy glucose (2DG), they concluded that insulin-induced glucose uptake is increased in adipose tissue [9]. The current study reports that pravastatin increases plasma adiponectin levels which were associated with a reduction in the risk of type 2 diabetes mellitus [10].

In reducing the risk of insulin resistance development, the triglyceride-lowering effect of pravastatin therapy may be significant over the longer term. For several years, high triglyceride levels have been known to have been associated with diabetes development [11].

Pravastatin is shown to reduce the circulating concentration of the interleukin-6, cytokines, and TNFalpha [12]. These inflammatory mediators inhibit lipoprotein lipase and stimulate lipolysis in adipose tissue [13,14]. These tissue-derived cytokines are responsible for insulin resistance metabolic syndrome. Pravastatin's anti-inflammatory properties interrupt the natural progression from central obesity to insulin resistance mediated by cytokines from the adipose tissue [6].

The influence on endothelial function is another effect of pravastatin consistently demonstrated [14-16]. The endothelial function has recently been decreased and correlations with the degree of insulin resistance have also been shown [17]. Pravastatin can significantly impact selective tissue perfusion through restoring the endothelial function and thus benefit the transportation of glucose and insulin [6].

The risk of developing diabetes and macrovascular complications was lower in patients receiving pravastatin. Therefore, it may be recommended to prescribe statins which are neutral in glucose homeostasis [18]. The connection between statin therapy duration and the risk of newly diagnosed diabetes is uncertain [19]. However, a recent study has found that compliance with statin therapy causes an increase in the risk of statin-induced diabetes mellitus [20]. Figure 1 provides the systematic representation of mechanism of action of statins [21]. Table 1 Summarizes the mechanism of pravastatin associated with diabetes mellitus.

Table 1: Summary of mechanisms od pravastatin associated with the Diabetes mellitus.

\begin{tabular}{|c|l|}
\hline Drug & $\begin{array}{l}\text { Possible mechanism's associated } \\
\text { with reducing diabetes mellitus }\end{array}$ \\
\hline \multirow{5}{*}{ Pravastatin } & $\begin{array}{l}\text { Increasing plasma adiponectin levels, } \\
\text { thereby reducing the risk of diabetes } \\
\text { mellitus }\end{array}$ \\
\cline { 2 - 2 } & $\begin{array}{l}\text { Long term reduction triglycerides } \\
\text { levels, reduces the risk of insulin } \\
\text { resistance development }\end{array}$ \\
& $\begin{array}{l}\text { Reducing the levels of inflammatory } \\
\text { mediators }\end{array}$ \\
\cline { 2 - 2 } & $\begin{array}{l}\text { Restore the endothelial function } \\
\text { enhancing }\end{array}$ \\
\hline
\end{tabular}

\section{Conclusion}

Patients who were taking pravastatin had a decreased risk of diabetes compared to patients who were taking other diabetes statins. Thus, it may be advisable to prescribe statins that neutrally or positively affect glucose homeostasis. 


\section{Acknowledgment}

We acknowledge that the work involved in this paper is well cited and properly addressed.

\section{Conflict of Interest}

The authors declare no conflict of interest.

\section{Funding}

None.

\section{References}

1. Haffner SM, Stern MP, Hazuda HP, et al. Cardiovascular risk factors in confirmed prediabetic individuals; does the clock for coronary disease start ticking before the onset of clinical diabetes? JAMA 1990; 263: 2893-2898.

2. Schmidt MI, Duncan BB, Sharrett AR, et al. Markers of inflammation and prediction of diabetes mellitus in adults (Atherosclerosis Risk in Communities study): a cohort study. Lancet 1999; 353: $1649-1652$.

3. Jahangir MA, Khan R, Imam SS. Formulation of sitagliptin-loaded oral polymeric nano scaffold: process parameters evaluation and enhanced antidiabetic performance. Artificial Cells, Nanomedicine, and Biotechnology 2018; 46(sup1): 66-78.

4. Jahangir MA, Imam SS, Kazmi I, et al. Type 2 Diabetes Current and Future Medications: A Short Review. Int J Pharm Pharmacol 2017; 1: 101.

5. Prasad VSS, Dattatreya A, Dhilleswara RV, et al. Nutritional Components Relevant to Type-2Diabetes: Dietary Sources, Metabolic Functions and Glycaemic Effects. J Res Med Dental Sci 2018; 6: 52-75.

6. Freeman DJ, Norrie J, Sattar N, et al. Pravastatin and the development of diabetes mellitus: evidence for a protective treatment effect in the West of Scotland Coronary Prevention Study. Circulation 2001; 103: 357-62.

7. Kobashigawa J, Katznelson S, Laks H, et al. Effect of pravastatin on outcomes after cardiac transplantation. N Engl J Med 1995; 333: 621-627.

8. Takagi T, Matsuda M, Abe M, et al. Effect of pravastatin on the development of diabetes and adiponectin production. Atherosclerosis 2008; 196: 114-121.

9. Rossmeisl M, Rim JS, Koza RA, et al. Variation in type 2 diabetes-related traits in mouse strains susceptible to diet-induced obesity. Diabetes 2003; 52: 1958-1966.

10. Spranger J, Kroke A, Mohlig M, et al. Adiponectin and protection against type 2 diabetes mellitus. Lancet 2003; 361: 226-228.

11. Rosenson RS, Tangey CC, Casey LC. Inhibition of proinflammatory cytokine production by pravastatin. Lancet 1999; 353: 983-984.

12. Kawakami M, Pekala PH, Lane MD, et al. Lipoprotein lipase suppression in 3T3-L1 cells by an endotoxin-induced mediator from exudate cells. Proc Natl Acad Sci USA 1982; 82: 912-916.

13. Hardardottir I, Grunfeld C, Feingold KR. Effects of endotoxins and cytokines on lipid metabolism. Curr opin lipidol 1994; 5: 207-215.

14. Egashira K, Hirooka Y, Kai H, et al. Reduction in serum cholesterol with pravastatin improves endothelium-dependent coronary vasomotion in patients with hypercholesterolemia. Circulation 1994; 89: 2519-2524

15. Muramatsu J, Kobayashi A, Hasegawa N, et al. Hemodynamic changes associated with reduction in total cholesterol by treatment with the HMG-CoA reductase inhibitor pravastatin. Atherosclerosis 1997; 130: 179-182.

16. Williams JK, Sukhova GK, Herrington DM, et al. Pravastatin has cholesterol-lowering independent effects on the artery wall of atherosclerotic monkeys. J Am Coll Cardiol 1998; 31: 684-691.

17. Serné EH, Stehouwer CDA, ter Maaten JC, et al. Microvascular function relates to insulin sensitivity and blood pressure in normal subjects. Circulation 1999; 99: 896-902.

18. Chen YH, Yang YC, Chen W, et al. Risk of macrovascular complications in statin-treated patients developing diabetes. Diabetes Res Clin Practice 2019; 157: 107870.

19. Newman CB, Preiss D, Tobert JA, et al. Stan Safety and Associated Adverse Events- A Scientific Statement from the American Heart Association Arterioscler Thromb Vasc Biol 2019; 39: e38-e81.

20. Corrao G, Compagnoni MM, Rea F, et al. Clinical significance of diabetes likely induced by statins: Evidence from a large population-based cohort. Diabetes Res Clin Pract 2017; 133: 60-68.

21. Jahangir MA, Bhisht P, Muheem A, et al. Diabetes: pharmacological history and future management strategies. Pharmaceutical Bioprocessing 2017; 5: 54-65. 
Citation Ramu G, Bhavya CH, Vamshi KD, et al. Effect of Pravastatin on Development of Diabetes Mellitus - A Statement of Review. Int J Pharm Pharmacol 2020; 4: 148. doi: 10.31531/2581-3080.1000148

This manuscript was peer-reviewed Mode of Review: Single-blinded

Academic Editor: Dr. MA Jahangir

Copyright: (92020 Ramu G, et al. This article is distributed under the terms of the Creative Commons Attribution 4.0 International License (http://creativecommons.org/licenses/by/4.0/), which permits unrestricted use, distribution, and reproduction in any medium, provided you give appropriate credit to the original author(s) and the source, provide a link to the Creative Commons license, and indicate if changes were made. 